\title{
EURASIAN GAMBLES OVER CYPRUS' EUROPEAN PROSPECTS*
}

\author{
VASSILIS FOUSKAS
}

\begin{abstract}
A plethora of strategic analysts and historians, with or without expertise on the Cyprus issue, have recognised the crucial role of international factors on the Cypriot domestic political stage. Their rationale was chiefly based on the geo-political location of the island in the Eastern Mediterranean, overlooking the Middle East and the Suez Canal. In modern history, if Cyprus came to be under the grip of the dominant power in the Eastern Mediterranean, this was mainly so because it was seen as a launching pad towards the domination of oil and gas producing regions. Regrettably though, the recognition of the fact that the Cyprus issue remains perhaps the most intractable politico-strategic affair in international relations today, it has not led contemporary students of the issue to seriously advance their analyses beyond a mere acknowledgement of this fact. Admittedly, there is a lack of published material focusing on the international dynamics and strategic aspects of Cyprus today vis-à-vis its bid to join the EU. This paper thus plan to locate Cyprus in the global context of the US and EU policies in Eurasia and in the regional context of the greater Middle East, focusing mainly on the post-Cold War period. The requirement is to decipher the parameters and the linkages of the balance of power in the Eurasian region, and in its Near Eastern sub-region, to which Cyprus belongs.
\end{abstract}

\section{KEYWORDS}

Turkey; Cyprus; European Union; Geopolitics; Eurasia; TurkishGreek Relations; EU-Cyprus Relations.

\footnotetext{
*Editor's Note: This paper was submitted before the "Annan Plan" on Cyprus was made public, and the EU Copenhagen Summit in December 2002.
} 


\section{Introduction}

Over the years, a plethora of strategic analysts and historians, with or without expertise on the Cyprus issue, have arguably recognised the crucial role of international factors on the Cypriot political stage. By and large, their rationale was chiefly based on the geo-political location of the island in the Eastern Mediterranean, overlooking the Middle East and the Suez Canal. Myriad of top secret declassified documents have shed light on the linkages between the island's strategic site and the geo-political considerations of foreign and security analysts of superpowers in the greater Middle East. ${ }^{1}$ The ruling classes representing the (majority) Greeks and the (minority) Muslims - later Turkish Cypriots - on the island were periodically, and rather cleverly, manipulated by exogenous, far more powerful actors. Thus, in modern history, if Cyprus came to be under the grip of the dominant power in the Eastern Mediterranean, this was mainly so because it was seen as a launching pad towards the domination of oil and gas producing regions. Had the declining Ottoman Empire been aware of this overall strategic potential, it would have perhaps never leased Cyprus to Britain in 1878. Greece had its chances between 1912 and 1922, but its warships, although good at laying a grip on the Aegean islands, could not project power deeper into the Eastern Mediterranean. Had Greece been able during the Balkans wars, or soon thereafter, to do so guaranteeing the security of Britain's communication lines, Lloyd George's Britain would not have objected

\footnotetext{
${ }^{1}$ The following is only an indicative bibliography: Claude Nicolet, United States Policy Towards Cyprus, Menheim, Bibliopolis, 2001; Diana Weston Markides, Cyprus 1957-1963; From Colonial Conflict to Constitutional Crisis, Minneapolis, Minnesota University Press, 2001; Robert Holland, Britain and the Revolt in Cyprus, Oxford, Clarendon Press, 1998; Michael Attalides, Cyprus: Nationalism and International Politics, Edinburgh, Q Press, 1979; Farid Mirbagheri, Cyprus and International Peace-Making, London, Hurst, 1998; Suha Bölükbaş1, The Superpowers and the Third World: Turkish-American Relations and Cyprus, New York, University of Virginia Press, 1988; Ioannis Stefanides, Isle of Discord: Nationalism, Imperialism and the Making of the Cyprus Problem, London, Hurst, 1999; Christopher Hitchens, Hostage to History - Cyprus: From the Ottomans to Kissinger, London, Verso, 1997. I would like to thank the three anonymous reviewers of my paper for their invaluable comments. I truly hope that this version will meet their expectations.
} 
to this as long as a reasonable quid pro quo was offered on the part of Greece. $^{2}$

Arguably then, bar the study of Soviet policy toward Cyprus, ${ }^{3}$ we do indeed possess a remarkable number of scholarly works on the international and strategic aspects of the Cyprus issue dwelling on the period stretching from between the wars down to the 1970s. Regrettably though, the recognition of the fact that the Cyprus issue remains perhaps the most intractable politico-strategic affair in international relations today, it has not led contemporary students of the Cyprus issue to seriously advance their analyses beyond a mere acknowledgement of this fact.

Admittedly, there is a lack of published material focusing on the international dynamics and strategic aspects of Cyprus today vis-à-vis its bid to join the EU. At best, contemporary analysts of Cyprus-EU relations peripheralise the Eurasian and even the Near Eastern dimension of the issue, focussing instead on institutional aspects of the discussion and/or on themes concerning the 'structural adjustment' of Cypriot economy and society according to the norms of the EU. ${ }^{4}$ At

2In fact, Britain had at least twice offered Cyprus to Greece in return for the latter's participation in the war on the side of the allies and by way of assisting Serbia against Germany's and Bulgaria's combined attack. But Greece, facing serious domestic problems, declined the offer, see, Sir David Hunt, 'Cyprus: A study in International Relations', The 1980 Montague Burton Lecture on International Relations, University of Edinburgh, Edinburgh, 28 October 1980; Michael Llewellyn Smith, Ionian Vision: Greece in Asia Minor, 1919-1922, London, Hurst, 1998, p.15.

${ }^{3}$ I would like to stress that what we mainly know on the Cyprus issue is because of the archival work done in Britain, the US, Cyprus, in the Greek Ministry of Foreign Affairs and in the archives of the American Embassy in Athens [see the extraordinary work by Alexis Papachelas, The Rape of the Greek Democracy; the American Factor (in Greek), Athens, Estia, 1997]. We know almost next to nothing as regards, for example, the USSR's policy in Cyprus from the beginnings of the Cold War, to the present day. Also, there is a lot of work to be done in the files, for example, of the National Security Council of Turkey (Milli Güvenlik Kurulu - MGK) and in the Greek Ministry of Defence but, admittedly, access to them is rather difficult.

${ }^{4}$ For instance, Kevin Featherstone's sober account accepts that a solution to the Cyprus issue cannot be disentangled from a 'multidimensional chess game', but his 
worst - unfortunately, this is the largest category - they tend to become hostages to describing scenarios and contingencies in case either Greece or Turkey would turn out to be dissatisfied with the EU's policy in solving the Cyprus issue via the island's accession. ${ }^{5}$ In sum, when we come to grips with analyses concerning the EU-Cyprus relations, we usually come to realise that they brush aside crucial geostrategic dimensions of the Cyprus issue, dimensions which occupy a key position in the US and EU's economic, foreign and security policies. I argue that we need to have a sound understanding of the strategic context within which Cyprus's European gamble is located in order to pronounce solidly upon its EU prospects.

I would like to locate Cyprus in the global dynamic context of the US and EU policies in Eurasia and in the regional context of the greater Middle East, focusing mainly on the post-Cold War period. The requirement is to decipher the parameters and the linkages of the balance of power in the Eurasian region, and in its Near Eastern subregion, to which Cyprus belongs. The logical/analytical framework I attempt to construct on this issue in order to situate Cyprus' multidimensional geo-politics is that the US considers its strategic

chosen focus is rather the institutional dimension of the EU-Cyprus relations and the way in which the EU is strategically used by the Cypriot political class on security grounds; Kevin Featherstone, 'Cyprus and the Onset of Europeanisation: Strategic Usage, Structural Transformation and Institutional Adaptation', South European Society and Politics, Special Issue on 'Europeanisation and the Southern Periphery', Vol. 5(2), Autumn 2000, pp.141-162.

${ }^{5}$ This is, for example, the main theme of Neill Nugent in his, otherwise interesting, 'EU enlargement and the "Cyprus problem"', Journal of Common Market Studies, Vol. 38(1), March 2000, pp.130-150; of Oliver Richmond 'A perilous catalyst? EU accession and the Cyprus problem', The Cyprus Review, Vol. 13(2), Fall 2001, pp.125-131; and of Heinz Kramer, 'The Cyprus problem and European security', Survival, Vol. 39(3), Autumn 1997, pp.16-32. Although I have personally benefited from reading these texts, they nevertheless tend to be highly speculative, if not at times alarmist. See also, Clement Dodd, Storm Clouds over Cyprus, Cambridge, The Eothen Press, 2001, and Christopher Brewin, 'European Union perspectives on Cyprus Accession', Middle Eastern Studies, Vol. 36(1), January 2000, pp.21-34. For two altogether bad cases of presenting alarmist scenarios and partiality of views, see Nanette Neuwahl, Jean Monnet Working Paper 4, Cambridge MA, Harvard Law School, 2000; and Michael Stephen, The Cyprus Question, London, Northgate Publications, 2001. 
partnership with Germany and France as more important than that with Turkey. And that if the US is forced to choose -in terms of their primacy in the Western Eurasian theatre- between an Atlantic Germany leading the EU's eastward enlargement and Turkey, then the superpower would opt for Germany. Although never officially declared, I tend to believe that Greece's bet that it would block the EU enlargement if Cyprus is not admitted in the EU is almost entirely placed within the remit of this strategic assessment. ${ }^{6}$

Subsequently, I examine more closely Cyprus's European perspective by way of focusing on the political positions of both sides, Greek and Turkish Cypriot alike, trying to diagnose the underlying strategic reasons that underpin their positions. I argue that Greece and the Republic of Cyprus have employed the EU/Germany diplomatic card in the background and the legal card up front. Turkey, on the contrary, has counted on its own regional geo-strategic primacy and military superiority, with almost all other arguments put forward being epiphenomena of its strong geo-political dimension in order to buy time. My overall tentative assessment is that Cyprus' European membership was bound to hang on a positive diplomatic and strategic balance in the 1990s and early 2000s, meaning that Cyprus' European prospect may well produce a final settlement on the island. This would represent a major achievement for the EU, in that it would re-affirm a strong foreign policy stance, which differs in substance from that of Turkey and the US.

\footnotetext{
${ }^{6}$ I repeat, this should be read only as a tentative concluding remark, simply because we do not possess hard evidence on the part of the Greek side that that was and is the case. Nevertheless, to the extend that the witness of an insider can be used by the researcher while approaching 'historical truth', I should mention the public discussion I held with Christos Stylianides in London (17 March 2002), former Government Spokesman of the Republic of Cyprus, who admitted that in 1993-96 these strategic debates about the role of Germany and France that could potentially underpin Cyprus's EU bid, were held in the Greek Ministery of Foreign Affairs, at the time under the influence of Theodore Pangalos and Yiannos Kranidiotis; see also, Michalis Ellinas, 'A Lobby for Cyprus seminar on Cyprus and the EU', Eleuftheria (London edition, in Greek), 21 March 2002, p.6. I will be more specific on these issues below.
} 
However, the perspective of a just and lasting solution to the Cyprus issue via the EU factor may be thwarted, because in current affairs we cannot predict the degree of tactful defence, economic and political diplomacy that each party will pursue. Nor we can foresee the ways in which the Iraqi crisis could impact upon the bargaining diplomatic power of the states concerned and, first and foremost, Turkey. Thus, ceteris paribus, and as things stood in the early 2000s, Cyprus's EU membership had to take pace with or without a solution to the island's de facto division. This much we know. Going beyond that, it means falling into line with conjectures that are wholly alarmist and highly speculative. But stepping backwards, it means confining ourselves to an analysis of the official reports and statements of the parties involved, thus remaining on the surface of things.

\section{Strategic Assessment: Germany's Primacy and Cyprus- EU Relations}

I would argue for the geo-strategic primacy of Turkey in respect to that of Greece and Cyprus, but not in respect to that of the EU and/or Germany and Greece put together. As Brzezinski argues authoritatively, Germany, in the first place, and France are 'the Eurasian bridgehead(s) for American power and the potential springboard for the democratic global system's expansion into Eurasia'. ${ }^{7}$ The US's post-Cold War policy and strategic evaluation of the Near East are but an extension of its Cold War notions. No major geo-political break between the US Cold War and post-Cold War policy occurred with regard to Eurasia and its Near Eastern subregion. All geo-political actors have behaved within the remit of the transfiguration of the new balance of power in the 1990s. The US was the victor, European Germany and China became stronger, and Russia was the loser. In the 1990s, the Balkans was to be re-divided not between USSR/Russia and the US/West as in the 1940s, but between the US, Germany and Russia under the paramount supremacy of the former. A similar settlement the US is seeking to achieve in Central Asia and the Middle East, efforts that have been intensified particularly after September 11. The US has expanded/extended its Cold War hegemonic policies, it has not abandoned them.

\footnotetext{
${ }^{7}$ Zbigniev Brzezinski, The Grand Chessboard, New York, Basic Books, 1997, p. 74.
} 
Germany has been the driving force behind the EU eastward enlargement and France behind its southward Mediterranean and Middle Eastern projection. First proposed by the Italians in 1989, a Conference on Security and Co-operation in the Mediterranean (CSCM) was modelled after the Conference/Organisation of/for Security and Co-operation in Europe (OSCE) and was placed under French leadership. The French-Italian chorus was joined by other South European countries, as well as by 'North African countries, Turkey, Jordan, the PLO [Palestine Liberation Organisation] and the Labour Party leadership in Israel' ${ }^{8}$ This project evolved into the EuroMediterranean Conference in Barcelona in November 1995, which produced a more concrete partnership programme, providing for an 'Euro-Med' free trade area by 2010 and an increase of the EU aid to the region. ${ }^{9}$ Overall, the French idea is that 'free trade and more aid will enhance stability and prosperity on the Southern and Eastern Mediterranean rim, foster cross-border trade within that region, underpin the Middle East peace process, and help advance pluralism in a region where authoritarian government is the norm'. ${ }^{10}$ The 'EuroMed' project created another point of friction between France/EU and the US. The Americans were not invited to attend the Barcelona Conference and they had 'organised almost at the same time a Middle East/North Africa economic summit in Amman, Jordan (which Syria refused to attend), to which an impressive mix of industrialists, financiers and officials were invited'.11

Brzezinski concedes that as a percentage of overall budget Germany contributes to the EU 28,5 per cent, to NATO 22,8 per cent,

\footnotetext{
${ }^{8}$ Leon T. Hadar, 'Meddling in the Middle East?', Mediterranean Quarterly, No. 8, 1998 , p. 48.

${ }^{9}$ See, European Commission, Strengthening the Mediterranean Policy of the European Union: Establishing a Euro-Mediterranean Partnership, Bulletin of the European Union, Supplement 2, Luxembourg, 1995. See also the work edited by Richard Gillespie based around the UK-based journal Mediterranean Politics, as well as his The Euro-Mediterranean Partnership: Political and Economic Perspectives, London, Frank Cass, 1997; A more recent work is that edited by Marc Maresceau and Erwan Lannon, The EU's Enlargement and Mediterranean Strategies, London, Palgrave, 2001.

${ }^{10}$ Hadar, 'Meddling in the Middle East?', p. 49.

${ }^{11}$ Ibid., p. 52.
} 
to the UN 8,93 per cent and it is the largest shareholder in the World Bank and the EBRD (European Bank for Reconstruction and Development) -the latter being substantially involved in the EU's Stability Pact for the reconstruction of the Balkans. ${ }^{12}$ Germany is a global economic power and the politico-economic locomotive of the EU. Strategically positioned at the heart of Europe, Germany 'monitors' its Southern flank through Austria and its influence in the Balkans, its Eastern rims through Poland, Hungary, Romania and Ukraine, and its Western zone through its on-and-off partnership with France. Germany's leadership of EU's eastward enlargement is bound up with concrete geo-strategic considerations and is based on a notion of political federalism modelled after Germany's own. It is this notion of political federalism that the US wants to deter.

Britain is not a major geo-strategic player in Europe, but it is so in the framework of its Commonwealth position and its military attachment to the US. Greece's, Turkey's and Cyprus geo-strategic positioning today has remained structurally unaltered for the US in the Near Eastern theatre. More to the point, Cyprus geo-strategic significance has not been downgraded after the end of the Cold War and its merchant fleet enjoys the sixth largest registry in the world. 'The accession of Cyprus to the EU', Communications and Works Minister Averof Neophytou pointed out in April 2002, 'would boost the EU's shipping fleet by 25 per cent, increasing the EU's share of world shipping from 16 to 20 per cent'. ${ }^{13}$ Moreover, in 2001-02, Cyprus had advanced with Syria the construction of an undersea gas pipeline. Although the $\$ 200$ million project was delayed due to problems in the construction of a pipeline from Egypt to Syria, through which gas supplies destined for Cyprus would be pumped, the construction of the pipeline would enable Cyprus to export surplus gas to West European markets. ${ }^{14}$ Cyprus is a real asset and an invaluable geo-strategic bridge connecting Europe and the Middle East. The EU has both political and economic interests in allowing a united and independent Cyprus to enter its ranks.

\footnotetext{
${ }^{12}$ Brzezinski, The Grand Chessboard, p. 66 (footnote).

${ }^{13}$ 'Cyprus shipping improves its image', Cyprus News, No. 152, London, Cyprus High Commission, April 2002, p. 3.

${ }^{14}$ See, 'Gas pipeline decisions looming', Cyprus News, No. 150, London, Cyprus High Commission, February 2002, p. 3.
} 
But all the points made above amount to saying that, in principle, the Turkish pivot disqualifies in face of Germany's and France's eastward and Mediterranean enlargement drives respectively, and that the US has no intention whatsoever to jeopardise the EU's enlargement in Western Eurasia for Turkey's sake, as long as Germany adopts the US notion of 'enlarging the EU without federalising it'. But as every strategic assessment is subject to changes according to the shifting diplomatic, economic and power relations, we can only put forward and examine the practical validity of the following proposition. The terms under which the Cyprus issue may be solved by the EU factor are conditioned by the changing strategic and diplomatic terrain between EU states and the US in the Western Eurasia, that is the area stretching from Turkey's Caucasian borders to the Baltic and Ukrainian Germanic frontiers.

We cannot afford here to discuss the possibility of Cyprus being left outside the next EU enlargement due in 2003-04. Nor we can confine ourselves to predicting scenarios about the possible reaction of Greece or Turkey in case one of them turns out to be dissatisfied over its European prospects. As we have made clear earlier, we cannot limit our discussion to this sort of exercise. This is primarily because a politically responsible decision has been taken on the part of the EU, that the internationally recognised 'Republic of Cyprus' will join the club, regardless of whether a solution to the island's de facto division is found before accession. ${ }^{15}$ And the US, although it put forward some important qualifications, has acquiesced to this. Let us give a brief historical summary of the EU-Cyprus relations by way of raising aspects of the relational cleavage between Germany/EU, on the one hand, and the US/Turkey on the other. By doing so, we shall also become aware of the fact that the EU/Germany are not mere foreign policy pawns in the hands of the US, particularly when important regional geo-political interests are at stake.

\footnotetext{
${ }^{15}$ It should be noted that the Helsinki declaration made clear that before Cyprus' actual accession to the EU, the Commission 'will take into account all relevant factors'. This can be interpreted in every possible way, but the fact remains that top-ranking EU officials and key EU documents have since Helsinki stated that the 'Republic of Cyprus' will join the EU regardless whether or not a solution is found before accession.
} 
When Britain - Cyprus's largest market - joined the EEC in 1973, Cyprus managed to establish an Association Agreement with the Economic Communities in the same year. The Agreement was instrumental in providing for a customs union, which was to be accomplished in two consecutive stages. However, due to the disruption caused by the Turkish 'intervention' (20-22 July 1974) and 'invasion' (14-16 August 1974), the second stage commenced only after 1988. This stage was in turn split into two phases and the whole process was scheduled for completion by 2003 .

On 4 July1990 'the Republic of Cyprus' submitted its formal application to join the Communities as a full member. The Europeans, aware of the problem, nominated an observer to register possible problems and issues raised during the talks between the Greek and Turkish Cypriot leaderships. At the European Council meeting in Corfu in June 1993, when Greece was holding the EU's rotating Presidency, the EU took a further step putting on an equal footing the membership of Cyprus with that of East-Central European states. This alarmed Turkey and the US, but they had both been calmed somewhat down soon after that, as a customs union agreement between Turkey and the EU began to loom large. In a masterly deal crafted between the EU, Greece and Turkey under the auspices of the US (February-March 1995), the EU went far ahead to declare that entry negotiations with Cyprus could commence six months after the Amsterdam IGC of 1996. At the same time Turkey signed a customs union agreement with the EU. ${ }^{16}$

But perhaps the most important of all decisions taken, was that at the Luxembourg summit of 12-14 December 1997, in which Turkey was nearly humiliated, whereas and the US was forced to accept Germany's posture not to offer Turkey candidate status. From our analytical perspective, the Luxembourg summit was important in that it conferred to Cyprus candidate status, but not to Turkey, and that these developments took place under the auspices of Germany and Greece and despite US/Turkish disapproval. The most annoying thing for Turkey was that the EU announced two groups of candidates, and

\footnotetext{
${ }^{16}$ For further comments on this, see Tozun Bahcheli, 'Turkish Cypriots, the EU option and resolving ethnic conflict in Cyprus', in Andreas Theophanous et al. (eds), Cyprus and the European Union, Nicosia, Intercollege Press, pp.108, 119.
} 
Turkey figured in none of them. Moreover, most of the candidates were former Communist countries, that is to say 'enemies'. The first 'fast track' group consisted of the Czech Republic, Slovenia, Cyprus, Poland, Estonia and Hungary, and the second -which needed more preparation before joining- of Bulgaria, Lithuania, Latvia, Slovakia and Romania. The EU produced a nice statement to cajole the Turks pledging to bring them closer to the ranks of the Union, but to no avail.

'This overall set of circumstances', Alan Makovsky writes, 'and the growing Turkish conviction that Germany and Greece were intent on keeping them out of the EU at all costs (...) convinced the Turks that the solemn pledges in the summit communique, including the emphasis placed on an accession strategy to bring Turks "closer to the EU in every field", could not be trusted' ${ }^{17}$ In this context, it is interesting to note that although US officials did not disagree with the EU's decision and had publicly stated that Turkey should be treated like any other candidate country, in private they had criticised "European "shortsightness" and "lack of political ingenuity". ${ }^{18}$

The EU further consolidated its relationship with Cyprus, and in April 1998 formally opened discussions with it over the acquis. A month earlier, the Greek Cypriot President of the 'Republic of Cyprus', Glafkos Clerides had officially asked the Turkish Cypriot leadership to join the Cyprus accession negotiating team, but the Turkish side refused to do so. At the EU's June 1998 summit, Mesut Yilmaz had 'a sharp exchange of words with German Foreign Minister Klaus Kinkel', asserting that 'Germany's EU strategy in Central and Eastern Europe was merely a continuation of its Nazi-era Lebensraum policies'. ${ }^{19}$

\footnotetext{
${ }^{17}$ See, Alan Makovsky, 'Turkey's faded European dream', paper presented to the Conference 'The Parameters of Partnership: Germany, the US and Turkey', American Institute for Contemporary German Studies, the John Hopkins University, Washington DC, 24 October 1997, p. 52.

${ }^{18}$ Ibid., p.59. Sabri Sayarı also notes ('Turkish perspectives...', p. 40) that 'the US was a key player in pushing for the conclusion for the customs union agreement between Brussels and Ankara' but at Luxembourg it was 'unable to change the opposition, led by Germany and Greece, to Turkey's full membership of the EU'.

${ }^{19}$ Makovsky, 'Turkey's faded European dream', p. 55.
} 
The US was directly involved in every negotiating phase. It is no accident that at the historic Helsinki summit in December 1999, 'the EU agreed - under intense pressure by the US - to accept Turkey as a formal candidate for EU membership', while committing itself to parallel negotiations over Cyprus. ${ }^{20}$ In November 2000, also under intense pressure by the US, the European Commission proposed an accession partnership for Turkey, which came to be adopted in March 2001.

\section{US Qualified Support to Germany and Greece}

This protracted process of EU-Cyprus relations and the cleavage between Germany and the US that emerged, further supports our stand of the EU/Germany primacy vis-à-vis Turkey, but it also exemplifies that the US strategic leaning toward the pair is likely to be highly qualified and balanced. In addition, it proves that the Greek-Turkish conflict has global dimensions, not only because of its energy security, pipeline projects, hence its geo-political significance, but also because it is internationally institutionalised mainly by way of NATO and the EU. From this perspective, powers such as Germany and France may periodically, and for their own reasons, support Greek positions in the $\mathrm{EU}$, in spite of their declared wish to 'stay clear of Greek-Turkish disputes'. ${ }^{21}$ The EU could not back down with regard to Cyprus's accession and the US could not put pressure on Germany/EU to do otherwise, except by asking them to qualify their position in favour of Turkey. Henri Barkey and Philip Gordon had perceptively commented on some of these issues as follows:

A crisis over the island's EU accession could dramatically raise regional tensions, undermine Turkey's difficult but steady evolution

${ }^{20}$ William Wallace, 'Rare optimism on Cyprus', Wall Street Journal Europe, 21 February 2002, p. A9;

${ }^{21}$ Tozun Bahcheli fails to see the dual geo-political and institutional/global dimension of the Greek-Turkish dispute, thus confining himself to the obvious assertion that EU states 'would prefer to stay clear of Greek-Turkish disputes, but Greece's membership has made this impossible'. In essence, Bahcheli discards the independent role of Germany at the Luxembourg summit altogether. See his ‘Turkish Cypriots', p. 119. 
toward Europe, and create fissures among EU members. All this would leave the US caught between its desire to promote a wider and more prosperous Europe and its inclination to stand by its Turkish friends. In the face of these risks, trying to dissuade the EU from fulfilling its promise to accept Cyprus is tempting, but it is not a realistic option (my emphasis). Given the EU's commitments and interests, such an American intervention is unlikely to succeed which EU member would or could agree to carry Washington's water on this issue? - and thus would lead only to needless tensions with Europe, Greece and Cyprus. An American attempt to block the Cyprus accession would also mean reversing the long-standing position of Democrats and Republicans that Cyprus should be eligible to join the EU; it would remove any remaining pressure on the Turkish side to accept a political settlement; and perhaps more importantly, it would lead to Greece's certain veto of EU enlargement to any of other pending candidates. That would create a crisis within Europe, which is the last thing the US needs or should care to be blamed for. ${ }^{22}$

The most important qualification the US put forward had to do with the entry of Turkey into the EU 'as soon as possible'. We also know that, in parallel with this, the US aimed at drawing Greece and Turkey closer, developing closer economic, political and strategic ties, a locomotive that has been at work since the mid-1990s, and not in Autumn 1999, following the devastating earthquakes in both countries. ${ }^{23}$ At the same time, both the UK and the US appeared to be supportive of the Turkish position concerning the ways in which the acquis could be implemented in Cyprus. In the main, this thorny issue

\footnotetext{
${ }^{22}$ Henri J. Barkey and Philip H. Gordon, 'Cyprus: the predictable crisis', The National Interest, No. 66, Winter 2001/02, http://nationaliterest.org/issues/66/BarkeyGordon.html', p. 10.

${ }^{23}$ Many analysts have made that mistake, including Barkey and Gordon (ibid., p.4). The Greek-Turkish rapprochement has been a long and protracted process of halfhearted initiatives on behalf of both countries, and began with the lifting of the Greek veto over Turkey's customs union agreement with the EU. As far as the Greek side is concerned, the strategic mind behind both the rapprochement and Cyprus' European bid, was Nikos Kranidiotis, the Cypriot-born Greek deputy Minister of Foreign Affairs, who was killed in a plane crash accident in Romania in 1999; see also the views expressed by Christos Stylianides, in Ellinas, 'A Lobby for Cyprus'.
} 
is linked with the allowance of extensive derogations, meaning imposition of certain limitations to the implementation of freedom of movement of persons, capital, payment and the settlement of some 200,000 Greek and 60,000 Turkish Cypriot displaced persons. ${ }^{24}$ But it would also mean that the refugees, the sole possessors of the legitimate title deeds since 1974-75, might be asked to seek compensation instead of return to, re-settling in, and economic use of their land and properties. In January 2002, soon after the two Cypriot leaders, Glafkos Clerides and Rauf Denktash, resumed talks under EU and US pressures, an authoritative Editorial comment of Financial Times stated:

The shape of a likely settlement is already clear. Cyprus will need to become a bizonal federation, with a single executive and shared presidency but maximum autonomy for the two parts. The North must be flexible over its territorial claims on parts of the South. While a settlement should include a right to return for Greek Cypriots, in practice they should be encouraged to accept compensation. Nor can there be completely free movement of people and capital across the island. The EU should allow the necessary derogations. ${ }^{25}$

\footnotetext{
${ }^{24}$ Derogations from the fundamental principles of the acquis are possible and are rather easily obtainable when they are temporary (e.g. the case of purchase of second holiday homes in Austria). Some permanent derogations are also possible and regard items without a serious political impact, such as the issue of tobacco snuff in Sweden. The most extreme form of derogations to date has been that implemented to Finland regarding the Aland islands. These Baltic Sea islands (some 6,5000) belong to Finland, but the majority of their population is Swedish, and various agreements since 1922 stipulate that a regional citizenship applies to them and that Finnish people need five years permanent residence to be able to buy real estate and start doing business. The whole issue 'posed major difficulties for the EU during negotiations, but the Accession Treaty for Finland maintained the restrictions on real estate ownership, establishment, exercise of profession and services for those not having regional citizenship, but held that these would be non-discriminatory and would apply to all the citizens of the Union'; see, Costas Apostolides, 'The European acquis communautaire and a federal Cyprus', in R. C. Sharma and Stavros A. Epaminondas (eds.), Cyprus: In Search of Peace and Justice, New Delhi, Somali Publications, 1997, pp. 258-59.

${ }^{25}$ Editorial, 'Cyprus surprise', Financial Times, 18 January 2002, p.14.
} 
Seen from this angle, the implementation of extensive or even permanent derogations would, at least in theory, allow Turkey to maintain significant, ethnically seperated, territory on the island for political and military purposes, a design whose origins can be traced back to the old schemes of partition of the 1960s and early 1970s. Thus, the issue of Cypriot refugees is inextricably linked with the Turkish security posture since the mid-1950s, according to which either an independent Cyprus dominated by the Hellenic element, or a Cyprus united with Greece, would be a severe blow to Turkey's geopolitical and strategic interests in the Near East. The US and the UK have somewhat to go along with the Turkish notion, not least because they were the main inventors of the various separatist plans between 1957 and 1974. But the issue is far more complicated.

\section{Greek and Turkish Arguments}

The EU could not easily acquiesce to the US-UK wish for permanent derogations, because Turkey has transfered to Cyprus some 100,000 Anatolian settlers, most of whom have been lodged into abandoned Greek Cypriot properties. This Turkish move, which was basically aiming at altering the demographic composition of the island, has become a political and moral obstacle to the implementation of derogations on the part of the EU. Although eager to compromise on the grounds of a limited implementation of the acquis which would satisfy the Turkish side, the EU was left with no option but to acquiesce to legal opinions, which assented the illegality of population transfers. ${ }^{26}$ At any event, the EU aimed at having a united Cyprus into its ranks or, as characteristically was said, "with one voice, so as to be able to perform its obligations'. ${ }^{27}$

\footnotetext{
${ }^{26}$ See, European Union, 2001 Regular Report on Cyprus's Progress Towards Accession, Brussels, Office for Official Publications of the European Communities, COM, 2001, pp. 3-34; See also the legal opinion on the issue of settlers delivered by a team of ten professors of International Law, Christopher Greenwood, Alain Pellet, Gerhard Hafner et al, Legal Issues Arising from Certain Population Transfers and Displacements on the Territory of the Republic of Cyprus in the Period Since 20 July 1974, London, Press and Information Office, Cyprus High Commission, 30 June 1999.

272001 Regular Report, p. 5, 21, passim.
} 
The problems with the Turkish strategy were and are indeed legal. An argument put forward by Turkey in support of its 'separatist' position in Cyprus was that the two ethnic communities could not live together, witness the ethnic strife and anomalous situation before 1974 and the nearly impeccable peaceful order on the island since. This argument, rather overlooked by the Greeks, was often presented in the wider historical context of Greek-Turkish relations, whose remarkable degree of peaceful coexistence as separate states has been due to the exchange of populations between them in the 1920s. In this context, the Turkish side saw the international recognition of the self-styled Turkish Republic of Northern Cyprus - to date recognised only by Turkey - as condition sine qua non for a solution to the Cyprus issue inside or outside the EU. However, this Turkish stance, which is based on the creation of a fait accomplis in 1974, complicated matters, as the EU could not go against the resolutions of the UN Security Council, which has denied recognition for the Turkish enclaves since 1963-64, and for the Turkish zone since 1974. If the opposite ever occurs, then this (a) would deprive the UN of any seriousness and (b) would mean legitimising the displacement of some 250,000 persons, both Greek and Turkish Cypriots, by the Turkish forces in 1974.

Another argument put forward by Turkey was that Cyprus could not assume membership of any international organisation, i.e. of the $\mathrm{EU}$, if Turkey itself was not a member. Turkey attempted to draw legitimacy for this argument from the 1960 Treaty of Guarantee, namely Articles I(2) and II(2). ${ }^{28}$ However, the argument was countered by other legal opinions, which claimed that those articles were not concerned with membership in regional economic associations, but with union with another state. Indeed, as James Crawford, Alain Pellet and Gerhard Hafner put it, the purpose of these articles was to prevent union of Cyprus, or of any part of it, with Greece or Turkey, as well as to forbid the partition of the island. ${ }^{29}$ The EU accepted this legal

${ }^{28}$ See, Cyprus, Appendix B, 'Draft Treaty of Guarantee', Cmnd 1093, Nicosia, Republic of Cyprus, July 1960, p. 86.

${ }^{29}$ See, James Crawford, Alain Pellet and Gerhard Hafner, 'Republic of Cyprus: Eligibility for membership', United Nations, A/52/481, S/1997/805, 17 October 1997. Turkey has twice replied with an opinion written by Professor Maurice Mandelson, supporting that Cyprus's application is illegal (see, for example, Turkey-Maurice Mandelson, UN A/56/451, S/2001/953, 5 October 2001). 
opinion, and the US-UK went along with it, whatever their private reservations. Thus, in a recent FCO (Foreign and Commonwealth Office) document made available in public on 12 March 2002, we read:

The British Government does not accept the Turkish Government's assertion that Cyprus's application to join the European Union is illegal. In the Government's view there is no legal obstacle to Cypriot membership of the EU, since EU membership does not constitute 'union with another State' and is therefore not ruled out by the Treaty of Guarantee. The Government subscribes to the legal analysis in the joint Crawford/Hafner/Pellet opinions on this point. The Government's view of the legal position is also supported by the actions and statements of other EU member States, the European Commission and the UN Security Council. ${ }^{30}$

Having said this, Greece's tactful diplomacy in the 1990s in support of Cyprus's European bid, as well as its attitude to acquiesce to the US-EU demand for rapprochement with Turkey, seemed to have put Turkey with its back against the wall. Turkey was thus left with no serious diplomatic option other than to dig into a self-entrenched policy, insinuating the annexation of the zone it seized in 1974 if the EU admits the Greek Cypriot recognised state prior to a political settlement. Greece's predictable response was that it would block not only Turkey's European efforts, but also the very process of the EU eastward enlargement. But Turkey had a rough Turkish Cypriot negotiator, Rauf R. Denktaş, whose 'walk out' attitude in the bicommunal talks during the 1990s 'has strengthened the Greek Cypriots' hand, relieved them from having to negotiate, and made it difficult for the EU to do anything but include Cyprus in its ranks' ${ }^{31}$

I would like to argue that Turkey's allusion to annex ation of Northern Cyprus was backed by its strong military posture in Cyprus more than in the Aegean, and by its key geo-political importance for

Crawford, Pellet and Hafner replied again reinforcing their arguments further; see their 'The eligibility of the Republic of Cyprus for EU membership', London, Press and Information Office, Cyprus High Commission, January 2002.

${ }^{30}$ Jack Straw and Matthew Hamlyn, FCO/FAC/002-02, House of Commons, London 12 March 2002, pp. 1-2.

${ }^{31}$ Barkey and Gordon, 'Cyprus: the predictable crisis', op.cit., p. 5. 
the US. I would also like to maintain that Greece's threat to block the EU eastward enlargement pertained to Germany's primacy in Western Eurasian vis-à-vis Turkey's, a primacy supported by the US.

\section{Military Diplomacy by the 'Turkish Pivot'}

Turkey's strongest trump card was and is indeed military and strategic. Turkey knew that the post-1974 status quo in Cyprus serves not only its national interests (e.g. exclusion of Greece from the Eastern Mediterranean, and pressure on Greece to drawing a median line in the Aegean) but those of the US too. The Turkish presence in Cyprus attributed strategic and intelligent depth to the Turkish-Israeli axis, while overseeing Turkey's Hatay province -which is claimed by Syria- from the Karpass penisula of Cyprus. Additionally, it facilitates control over air and sea routes critical for the defence of Israel and the advancement of the US interests in the South-eastern coastal strip of the Mediterranean. As far as its Eastern Mediterranean positioning is concerned, Turkey's strategic role today runs indeed on the same Cold War track. ${ }^{32}$ Thus, Turkey is a key guarantor for the US, not least because its Anatolian landmass provides for the integrated security of possible crude oil transportation from the Caspian and the Caucasus to the Mediterranean, such as the Baku-Ceyhan plan. ${ }^{33}$

The US apart, Turkey, somewhat more than the UK or Greece, has the potential to be defined as a real sovereign power on Cyprus, irrespective of whether or not it keeps its infantry on the island. As we know from the political and legal philosophy of Carl Schmitt,

\footnotetext{
${ }^{32} \mathrm{Cf}$., Süha Bölükbaşı, 'Behind the Turkish-Israeli alliance: A Turkish view', Journal of Palestine Studies, Vol. XXIX(1), Autumn 1999, pp. 26 ff.; and Marios Evriviades, 'The Turkish-Israeli axis: Alliances and alignments in the Middle East', Orient, Vol. 39(4), 1998, pp. 565-582. Evriviades' analysis is deeper and more sophisticated than that by Bölükbaş1, although both writers seem to agree that the Turkish-Israeli military axis comes a long way (this is more pronounced in the analyses of Evriviades). It should also be noted that whereas in the 1950s, the Turkish-Israeli axis was initiated by Israel, in the 1990s it was the Turks that had begun courting the Israelis.

${ }^{33}$ Inter alia, Zalmay Khalilzad et al. (eds), The Future of Turkish-Western Relations: Toward a strategic Plan, Santa Monica, Rand, 2000, passim.
} 
sovereignty is less related to a legal notion, than to a political one. According to Schmitt, politically sovereign are not those, whose democratic Constitution says so, but those who can decide the state of emergency over a given territory. ${ }^{34}$

True, Turkey's politico-military grip over Cyprus is restricted by the US's far superior posture in the Eastern Mediterranean, as well as by the UK and/or Greece, put separately or jointly. In the event, Turkey's real sovereignty is also limited by the EU, due to the very institutional and political framework of relations between the EU and Cyprus that has been developing since 1990. However, the point at issue is that we have been presented with several examples, which illustrate Turkey's primacy when it chose to stake out maximalist positions backed by the threat of force. If this Turkish primacy is true, then the argument developed by Turkey concerning the formation of two sovereign states (the co-federal solution) in view of protecting the Turkish Cypriot community from Greek nationalists, does not make much sense. It could only make legal sense which, in turn, could impact positively on the political and economic status of the Turkishrun zone, which has been refused international recognition. In fact, by recognising the Turkish zone as an independent state via a co-federal solution, or what the Turkish Foreign Minister İsmail Cem called in 2002 as 'partnership state', ${ }^{35}$ Turkey could legitimise its strategic positioning in Cyprus reversing all negative political and international

${ }^{34}$ See Carl Schmitt, Der Begriff des Politischen, Berlin, Dunker \& Humbolt, 1932. Schmitt, who died in 1982, was the leading Nazi jurist during the inter-war period. His philosophy should thus be seen as an attempt to lay the underpinnings of the Nazi dominance of Europe by force. Despite this political shortcoming, Schmitt's work is widely recognised as one of the most important and penetrating analyses in the field of modern political theory. On this issue, I am mostly indebted to the analyses put forward by Peter Gowan in his, 'The Twisted Road to Kosovo', Labour Focus on Eastern Europe [single issue], No. 62, Spring 1999, pp. 74-5,

${ }^{35}$ Ismail Cem, 'A common vision for Cypriots', International Herald Tribune, 14 March 2002, p. 6. A better elaborated view of this notion is developed by Ergun Olgun, under-secretary to Rauf Denktash, in his 'Time running out for the dètente in Cyprus', The European Voice, 8-15 May 2002. The Greek Foreign Minister, George Papandreou, responded with an article that was characteristically entitled 'A unified Cyprus is essential for European unity', International Herald Tribune, 2 May 2002. 
consequences stemming from the 'full-scale invasion' of August 1974. But let us look at two examples, one in relation to Turkey's tactics toward Greece and Cyprus, and one towards the UK, which show the gains of Turkey when putting forward maximalist positions.

In 1998, when Turkey found out that the Greek Cypriot Government was ready to import the Russian-made SS-300 ground-toair missile system, it threatened to destroy them on the way to Cyprus, by using military force. ${ }^{36}$ In order to defuse the tension, both the EU and the US urged Greece and the Republic of Cyprus to abandon the idea of deploying the system in Cyprus. The Greek Cypriot Government, under enormous pressure from Greece -at the time striving to reach the EU criteria for monetary integration- backed down. The missiles, although purchased, never arrived in Cyprus and they were stored somewhere in Crete. Thus, thanks to Turkey's tough line, the deeply unequal balance of force on the island between the Greek and the Turkish sides remained unaltered. ${ }^{37}$

At times, Turkey attempted to outflank/undermine even the UK's position in the region. It is argued that Turkey's longer-term aim since the mid-1950s has been the strategic control of the whole of Cyprus, and one way to achieve this is by acquiring a form of shared political sovereignty with the Greeks over the South, while at the same time in full control of the North. ${ }^{38}$ In the main, this is the reason why

${ }^{36}$ For a good background of the events and analysis, see Makarios Drousiotis, 'S300 and other myths', [in Greek], Archeio, No. 1, December 1999.

${ }^{37}$ There is a wide consensus that the military deployment of missiles would have had a minor impact on the overall relationship of military force on Cyprus. Nevertheless, Turkey opposed their installation for preventive reasons; see, for instance, Dan Lindley, 'The military factor in the Eastern Mediterranean', in Clement H. Dodd (ed), Cyprus: the Need for New Perspectives, Cambridge, The Eothen Press, 1999, pp. 195-230; On the issue of military balance in Cyprus before the case of S-300 broke out, see Aristos Aristotelous, Greece, Turkey and Cyprus; the Military Balance, 1995-96, Nicosia, Cyprus Centre for Strategic Studies, 1995.

${ }^{38}$ In essence, as a former political advisor to George Vassiliou explains, 'the political solution Turkey wants in Cyprus is a Turkish state in the North and a Greco-Turkish state in the South'; see, Andreas Theophanous, Cyprus in the European Union and the New International Environment (in Greek), Athens, 
Turkey opposes the 'double union' solution, even if this would mean legitimising its presence in northern part of Cyprus. In point of fact, Turkey does not wish to have Greece in its underbelly, because this cannot exclude neither a strategic partnership between Greece and Israel, nor Turkey's actual encirclement by Greece. But beyond this, control over the Southern zone is blocked by some significant powers.

The two British sovereign bases in Akrotiri/Episkopi and Dekhelia, the Greek air base at Paphos - which was created in the framework of the united defence doctrine between Greece and the Republic- as well as France's presence in Cape Gkreko, constitute a serious obstacle to the Turkish strategy. ${ }^{39}$ Yet, Turkey has disregarded several times the British sovereign posture, as well as the UN buffer zone. In summer 2000, the Turkish forces moved the cease-fire line some 300 metres into the UN buffer zone, bringing under their control the small Greek Cypriot village of Strovilia, which was situated there. This was immediately denounced by the $\mathrm{UN}$, but the real issue lays elsewhere. By creating a new checkpoint into the UN zone, Turkey established a common border with the British sovereign base of Dekhelia, as Strovilia was the sole buffer preventing this from happening. This enhances Turkey's bargaining power and paves further the ground for an eventual take-over, if Britain ever evacuates its base or part of it.

Another blow to Britain was the arrest by Turkish forces of a Greek Cypriot from an UK sovereign base area on 12 December 2000.

I.Sideris, 2000, pp.103-04, passim. Theophanous, now a Professor of Political Economy at Intercollege, Nicosia, took part in important talks with the TurkishCypriot leadership in the early 1990s, when Vassiliou was President of the Republic. Although one cannot be unequivocal about this until after we had access to relevant documents, the fact is that since the mid-1950s Turkey's maximum goal has been the strategic control of the whole of Cyprus; see also Vassilis Fouskas, Zones of Conflict; US Foreign Policy in the Balkans and the Greater Middle East, London, Pluto Press, 2003, chapter 4.

${ }^{39}$ This joint defence doctrine between Greece and Cyprus, among others, stipulates that any further advance of the Turkish forces in Cyprus would be a casus belli for Greece. France has a listening post in Cape Gkreko, South-eastern Cyprus, and it also transmits from there radio programmes in both French and Arab in the Middle East. France has been holding this site since 1970. I am obliged to former Cypriot diplomat Nikos Makris for this invaluable information. 
Allegedly, this was done because the Greek Cypriot was possessing 1,1 kilos of cannabis, but the UK police in the base admitted that no trace of drugs had been found on the Greek Cypriot. ${ }^{40}$

From this perspective, Turkey and the Turkish Cypriot leadership were not quite sincere when they argued for two sovereign states on Cyprus in order to safeguard their security in face of the threat posed by the majority Greek Cypriots. Rather, and having in mind the conditions of social and economic security generated in a European demilitarised Cyprus, this argument seems to be covering-up the real intention of Turkey, which is the strategic control of the entire island via a 'partnership state', and not the security of the Turkish Cypriots from Greek nationalists. At all events, Turkey can be one of the politically sovereign powers in Cyprus even without bothering to have a military presence on it (for example, as opposed to Greece, Turkish warplanes can reach Cypriot airspace almost instantly after taking off). Greece could not create a state of emergency in Cyprus with a fair chance to succeed, and the UK has no conceivable economic or political reason to do so. Thus, time and again, it appears that the argument for the maintenance of Turkey's troops in Cyprus is not connected with the security of the Turkish Cypriots, but with Turkey's long-term strategy of gaining strategic control of the whole of Cyprus.

Turkey's strategic stakes owe much to its military co-operation with Israel, a co-operation officially declared on 23 February 1996 in Tel Aviv, and reluctantly signed (December 1996) by then Turkey's Islamic Premier Necmettin Erbakan. ${ }^{41}$ This cooperation, which the US has encouraged, guided and participated in full, seems to be a serious stumbling block for the EU's distinctive strategy in the Middle East. Nevertheless, the issue is not so simple.

The US, Israel and Turkey have since 1996 been holding regular joint military exercises in the Eastern Mediterranean, and have

${ }^{40}$ See in particular, European Union, 2001 Regular Report, p. 21. After strong diplomatic pressure on Turkey, the Greek Cypriot was released in April 2001.

${ }^{41}$ Erbakan, who was known for his anti-semitic views, signed the pact under strong pressure from the military, only to be overthrown by it with the mini-coup of June 1997. From whichever angle ones examines the issue of Islam in Turkey, the fact remains that it is bad political news for the US and, for the secular military. 
increased intelligence co-operation and exchanges of military personnel for training purposes. ${ }^{42}$ Furthermore, Israel has become an established contractor for Turkey's sophisticated weaponry, and a security forum discussing strategic issues between the two states has been formed. ${ }^{43}$ In this context, it should be pointed out that the Turkish-Israeli axis has a Janus-face strategic implication.

In the first place, it certainly tends to weaken the Greek/Greek Cypriot geo-strategic posture in the wider strategic site of Western Eurasia and the Mediterranean, where Germany and France have a strong leverage through the EU or regardless. But at the same time it tends to downplay Turkey's bid to join the EU, since the EU's foreign policy position, for its own reasons, is clearly in favour of the Palestinians. ${ }^{44}$ However, this does not mean that an eventual entry of Turkey into the EU would not be to the detriment of the Turkish-Israeli axis, as Turkey may be forced to choose between Israel and the EU on hot policy and economic issues. Similarly, and even brushing aside the EU factor, the Turkish-Israeli cooperation, together with their combined pivotal role, may become redundant if the Mullahs of Iran decide to re-enter the US-led alliance in the Greater Middle East and/or if Iraq adopts pro-US positions, either by force or regardless. Time and again though, Greece and Cyprus come up in the equation, since they are the sole gateways to European politics and economic prosperity for both Israel and Turkey. ${ }^{45}$

In the light of this analysis, the following tentative concluding remarks seem to be inescapable. Turkey played the diplomatic card of military tension as it counted on its military superiority and regional geo-strategic primacy. The Republic of Cyprus and Greece play the

${ }^{42}$ See, Muhamoud A-Shaik, 'US-Israel-Turkey exercises could be a blessing in disguise', http://www.muslimedia.com/archives/oaw98/blessing.htm.

${ }^{43}$ Evriviades argues that that security forum institutionalises the relationship between Turkey and Israel, and is thus the most important long-term aspect of their cooperation. See Evriviades, 'The Turkish-Israeli axis', p. 569.

${ }^{44}$ Among others, Ben Soetendorp, Foreign Policy in the EU, London, Longman, 1999, pp. 95-113, Kirsten E. Schulze, The Arab-Israeli Conflict, Longman, 1999.

${ }^{45}$ This is also the main theme of Shmuel Limone, a retired Israeli General, in his 'Security issues in the Eastern Mediterranean and Europe: A view from Israel', in Theophanous et al., Cyprus and the European Union, pp. 189-196. 
EU and legal cards as they counted on Germany's pivotal role in Western Eurasia and on France's positioning in the Mediterranean and the Middle East. Additionally, Greece's EU and NATO memberships and its stabilising politico-economic role in the Balkans, have enabled Cyprus in the late 1990s and early 2000s to place its EU membership on a secure membership track. It remains to be seen the extent of constitutional and other modalities (e.g. the issue of derogations, the Turkish military presence in Cyprus) by which the EU would be in a position to advance the Cypriot cause of the island's political reunification.

\section{Conclusion}

I will confine myself here to summarise the main points of the discussion, in the hope that they will become the focus of a wider scholarly debate.

(a) The evolution of EU-Cyprus relations depends neither on the completion of negotiations over the acquis, nor on Greece's and Turkey's political volition to see the Cyprus issue solved according to their respective national interests. Rather, it depends on the strategic interests of the West, that is primarily the competing set of interests between key Eurasian powers, such as Germany, on the one hand, and the US, on the other.

(b) Turkey, despite its domestic political, economic and human rights shortcomings, continues to be seen by the US as more strategically important than Greece and considers Turkey's EU membership as condition sine qua non for its democratisation. The EU, however, appears to have a more substantial understanding of the 'Turkish Question', insisting on Turkey's democratisation prior to its membership. Turkey - and this is a fundamental difference between Cold and post-Cold War American thinking - is no longer viewed as a 'first line of defence' against Soviet Communism, but as a 'first line of aggression' in the greater Middle East and Central Asia. This displeases Turkey and the EU, both of which see the matter as a key security issue.

(c) On the wider Eurasian chessboard, Russia and China remain for the US the forces to reckon with. But on the 'friendly' Western Eurasian theatre, Turkey and Germany occupy pivotal positions 
for the promotion of the US interests. The US has nevertheless a strategic inclination toward Germany, and it seems that it is on the basis of this strategic assessment that Greece has developed its political strategy of blocking further EU enlargement in case Cyprus is not admitted.

(d) Greece and the 'Republic of Cyprus', in addition, employ legal/democratic arguments in order to achieve their aims, i.e. the Republic's EU membership. Turkey, employs legality and other normative issues only as a delaying tactics. Turkey's real trump card is its regional geo-strategic primacy in the wider Near East, backed by its military co-operation with Israel.

(e) We are thus coming to formulate our final assessment: Other things being equal, the 'Republic of Cyprus' will enter the EU because the strategic and diplomatic balance at the global and regional levels, at the time of writing (October 2002), tends to be on its favour. 


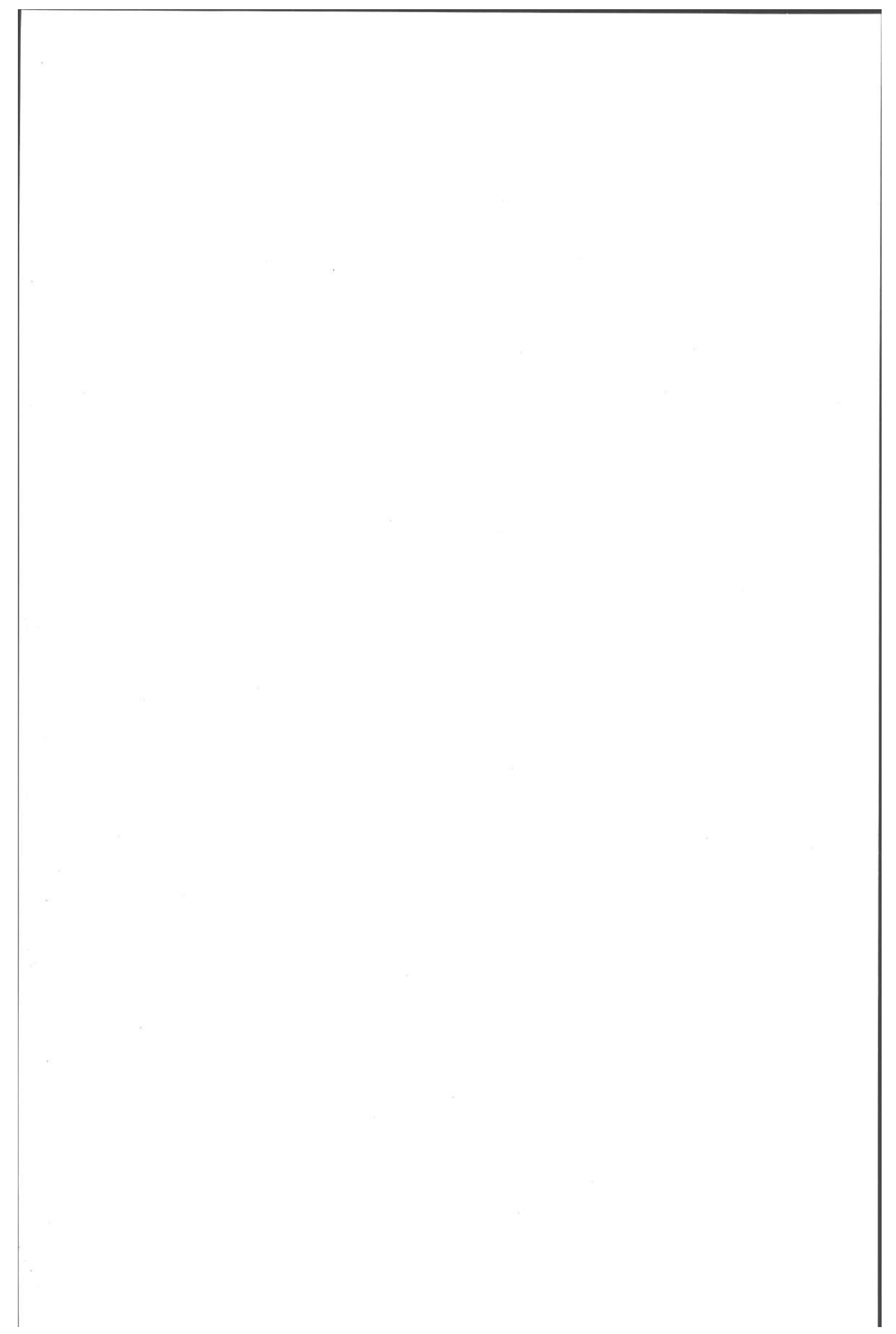

